\title{
The Contours of Profit-Making Activities of Non-Profit Companies: An Analysis of the New South African Companies Act
}

\author{
Maleka Femida Cassim*
}

\begin{abstract}
While for-profit companies regularly embark on non-profit activities, the converse issue has recently come to attention, namely whether non-profit companies may embark on profit-making activities. This has given rise to a confusing conundrum of practical importance, not only in South Africa but also in other jurisdictions. This article discusses whether non-profit companies, under the South African Companies Act of 2008, may have purely commercial objects. It also addresses the intertwined question of the contours of permissible profit-making activities. Since the non-profit company is the modern successor to the section 21 company under the previous Companies Act of 1973, this article considers the recent case of Cuninghame v First Ready Development 249, in which the Supreme Court of Appeal was faced with the problem of a section $21 \mathrm{com}$ pany with a commercial object. The article also explores the administration of rental pool agreements by non-profit companies, which arose in the Cuninghame case.
\end{abstract}

\section{INTRODUCTION}

It has in modern times become quite common for for-profit companies regularly to embark on non-profit activities and corporate social responsibility programmes. Recently, however, the spotlight has fallen on the converse issue in South African law, namely whether non-profit companies may embark on profit-making activities. This is a conundrum of substantial practical magnitude and a source of considerable confusion.

Closely intertwined is the quintessence of a "non-profit" company. By way of background, the new South African Companies Act 71 of 2008 (the New Act) provides for two broad categories of companies: "profit" companies and "nonprofit" companies. A profit company, by definition, ${ }^{1}$ is incorporated "for the purpose of financial gain for its shareholders". A non-profit company, in contrast, must be formed "for a public benefit object" or "an object relating to cultural or social activities or communal or group interests". ${ }^{2}$ The statute thus explicitly limits the purposes for which non-profit companies may be formed.

\footnotetext{
* $\quad$ MBBCh (cum laude), LLB (cum laude), LLM (cum laude) (Witwatersrand); senior lecturer, Faculty of Mercantile Law, University of Pretoria; attorney and notary public of the High Court, South Africa.

1 New Act, sec 1.

2 Id, sched 1, item 1(1)(a).
} 
In view of their uniqueness and distinctiveness, non-profit companies are not subject to all the requirements and prohibitions of the Companies Act. Instead, non-profit companies are subject to a modified application of the New Act, and are exempt from many of its parts and sections, such as rules on the capitalization of profit companies and the remuneration and election of directors. ${ }^{3}$ Unlike profit companies, non-profit companies do not have a share capital. Non-profit companies are furthermore subject to a distinct set of essential rules governing matters unique to them. The rules specifically regulating non-profit companies are set out in a separate schedule ${ }^{4}$ to the New Act. Flowing from these differences in the essential rules governing profit companies and non-profit companies, are significant practical consequences for non-profit companies. For example, an important innovation of the New Act is that a non-profit company need not have any members; the appointment of the directors of such a non-membership company may be made by the board itself or by other persons. ${ }^{5}$

Besides the essential difference in the objects or purposes of profit and nonprofit companies, a second key distinction is that, whereas a profit company may make distributions of money or other property to its shareholders, the fundamental principle at the heart of a non-profit company is that its income and property must not be distributed to its members or directors. ${ }^{6}$ It seems to be generally recognized and accepted in most jurisdictions, as discussed further below, that the essence of a non-profit company is that it is subject to such constraints on distributions to its members and controllers, regardless of whether those distributions take the form of dividends or distributions on winding-up.

Notwithstanding these basic principles, there is much mystery and confusion about exactly what it means to be a non-profit company. This confusion has been experienced not only under South African law, but more widely in other jurisdictions, including even the USA. ${ }^{7}$ The muddle and uncertainty fundamentally lie in the definition of a non-profit company and the purposes or objects for which a non-profit company may be formed.

Despite the label "non-profit" company, it must be underscored at the outset that, as a general principle, a non-profit company is not wholly precluded from making profits. A non-profit company may validly make profits, so long

3 See id, sec 10.

4 Id, sched 1.

5 On the basis set out in the company's constitution. See id, sched 1, items 4(1) and 5 .

6 Nor to its incorporators, officers or persons related to any of them, except to the extent permitted by the New Act. See sec 1 read with sched 1, item 1(3).

7 See for example HL Oleck "Mixtures of profit and non-profit corporation purposes and operations" (1988) 16 Northern Kentucky Law Review 225 at 236. See also H Hansmann "Reforming non-profit corporation law" (1981) 129 University of Pennsylvania Law Review 497 at 500: "The basic corporate law applicable to non-profit organizations is at a remarkably immature state of development, and remains startlingly uninformed by either principles or policy. Confusion continues to surround even the most fundamental issues, including the purposes for which non-profit corporations may be formed". 
as it complies with the basic prohibition on distributions to its members and controllers, and provided that all its assets and income, however derived, are applied to advance its stated objects. ${ }^{8}$ The question then arises whether it is also part of the essence of a non-profit company that it must be incorporated for a non-commercial object (or non-profit object) or is it permissible for nonprofit companies to have purely commercial objects?

This is a fundamentally important issue, which has substantial practical ramifications. This issue forms the focus of this article, together with the intertwined enquiry of the contours and boundaries of profit-making activities by non-profit companies under the New Act.

The importance of the non-profit entity in South Africa has formed a focal point of the corporate law reform process. Indeed it is a specifically stated purpose of the New Act to make provision for the formation, operation and accountability of non-profit companies in a manner designed to promote, support and enhance the capacity of such companies to perform their functions. ${ }^{9}$ This gives rightful recognition to the existing non-profit companies in South Africa, of which there are more than $20,000 .{ }^{10}$

The issue of whether non-profit companies may engage in purely commercial activities is especially relevant in the South African context, where a large number of companies with purely commercial objects were (with respect, incorrectly) incorporated as non-profit companies under the previous Companies Act 61 of 1973 (the 1973 Act). There are important practical reasons why such companies would prefer to be incorporated as non-profit companies and not as profit companies, as further discussed below. It is also vital in this regard to note that non-profit companies, which may wish subsequently to pursue purely commercial activities, are not permitted to convert to profit companies. ${ }^{11}$

This article critically discusses the extent to which the non-profit company may engage in purely commercial and profit-making activities under the New Act, which came into force in May 2011. The new non-profit company is effectively a metamorphosis of the former section 21 company (or association not for gain incorporated under section 21) of the 1973 Act. It is therefore germane also to take account of the recent case Cuninghame $v$ First Ready Development 249 (association incorporated under section 21) (Cuninghame), ${ }^{12}$ where the Supreme Court of Appeal was in fact faced with the very question of whether it is permissible for a section 21 company to have a purely commercial main object or purpose, so long as no distributions are made to its members.

8 Ie the objects set out in its constitution (New Act, sched 1, item 2).

9 Id, sec $7(\mathrm{~h})$.

10 According to statistics released by the Companies and Intellectual Property Registration Office.

111973 Act, sec 24 and New Act, sched 1, item 2(1).

122010 (5) SA 325 (SCA). 
The issue of whether rental pool arrangements constitute commercial activity arose incidentally on the particular facts of Cuninghame. This issue, with respect, was not fully considered by the court, but is explored in this article, for it serves as a useful illustration of the scope and ambit of "commercial" or profit-making activities by non-profit companies.

Reference is also made where relevant to the legal position in other comparable jurisdictions. Although South African company law has traditionally and historically been based on English company law, a number of new trends and concepts have been adopted from US and Canadian corporate law for the purposes of the New Act. Accordingly these jurisdictions form the basis of the comparative law perspective in this article.

\section{THE DEFINITION OF A "NON-PROFIT COMPANY" AND ITS OBJECTS}

A non-profit company, as stated above, is the modern successor to the association not for gain formed under section 21 of the 1973 Act (commonly known as a section 21 company). It is defined in section 1 of the New Act as:

“a company -

(a) incorporated for a public benefit or other object as required by item 1(1) of schedule 1; and

(b) the income and property of which are not distributable to its incorporators, members, directors, officers or persons related to any of them except to the extent permitted by item 1(3) of Schedule 1." (Emphasis added)

Item 1(1) of schedule 1, in turn, provides:

"The Memorandum of Incorporation of a non-profit company must -

(a) set out at least one object of the company, and each such object must be either -

(i) a public benefit object; or

(ii) an object relating to one or more cultural or social activities, or communal or group interests." (Emphasis added)

It emerges from these statutory provisions, read together, that there are two essential criteria for a non-profit company in South African law, both of which must be fulfilled. First, the company must be incorporated for a suitable object (or proper purpose) as set out in its constitution: either a public benefit object or an object relating to one or more cultural or social activities, or communal or group interests. Secondly, the income and property of the company as a general rule must not be distributable to its members or other persons, except as permitted by item 1(3) of schedule 1; for example, reasonable remuneration may be paid for services rendered by employees or directors. ${ }^{13}$

13 New Act, sched 1, item 1(3) states: "A non-profit company must not, directly or indirectly, pay any portion of its income or transfer any of its assets, regardless how the income or 
Significantly, both of these criteria must be satisfied in order for a company to qualify as a non-profit company under the New Act. This is clear from the use of the conjunctive word "and" between subparagraphs (a) and (b) of the definition of a non-profit company set out above.

At the crux of the matter is the interpretation and the ambit of the expression "communal or group interests". Would this expression embrace the undertaking of purely commercial activities by a non-profit company?

\section{MAY NON-PROFIT COMPANIES HAVE PURELY COMMERCIAL OBJECTS?}

On a proper interpretation and construction of the objects or proper purposes of a non-profit company, it is respectfully submitted that non-profit companies are proscribed from the pursuit of purely commercial activities. This is based on three main factors: the eiusdem generis [of the same kind] rule of interpretation; the purpose of the provision and the mischief at which it is aimed; and the element of "gain" as a distinction between profit companies and non-profit companies.

\section{Eiusdem generis interpretation}

It is submitted that the expression "communal or group interests" (in item 1(1) (a)(ii) of schedule 1 to the New Act) cannot properly be viewed as a stand-alone object, in itself, but must instead be interpreted eiusdem generis, that is, it must be construed with reference to the preceding words in the item. Since the common genus or common denominator of the preceding words is that they refer to associations pursuing cultural or social activities as opposed to purely commercial enterprises, the proper interpretation of the expression "communal or group interests" must relate to associations pursuing cultural or social activities in the interests of a particular community or group, as opposed to purely commercial enterprises. Significantly, this precludes a nonprofit company from engaging in a purely commercial activity as its object.

Authority for the eiusdem generis interpretation of the phrase "communal or group interests" is derived from the decision of the Supreme Court of Appeal in the recent case of Cuninghame, ${ }^{14}$ in which the court was faced with the crisp

contd

asset was derived, to any person who is or was an incorporator of the company, or who is a member or director, or person appointing a director, of the company, except (a) as reasonable (i) remuneration for goods delivered or services rendered to, or at the direction of, the company; or (ii) payment of, or reimbursement for, expenses incurred to advance a stated object of the company; (b) as a payment of an amount due and payable by the company in terms of a bona fide agreement between the company and that person or another; (c) as a payment in respect of any rights of that person, to the extent that such rights are administered by the company in order to advance a stated object of the company; or (d) in respect of any legal obligation binding on the company."

Above at note 12 . 
issue of whether a section 21 company may validly engage in a purely commercial activity. Although this decision concerned an association not for gain incorporated under section 21 of the 1973 Act, it would continue to have implications for non-profit companies under the New Act. Indeed, in the course of its judgment, the court specifically referred ${ }^{15}$ to the respondents' contention that the New Act (which had at the time not come into operation) would seem to allow for the equivalent of the section 21 company (ie the new non-profit company) to engage in purely commercial activities. This dubious contention requires closer scrutiny. The Supreme Court of Appeal in Cuninghame (correctly, with respect) rejected the respondents' contentions that the effect of the expression "communal or group interests" in the 1973 Act is that a section 21 company may have as its main object the promotion of any communal or group interests; it preferred instead to adopt a eiusdem generis interpretation of the expression, so as to exclude purely commercial enterprises from its ambit. 16

It is relevant that the main object of a section 21 company under the 1973 Act is defined similarly to (albeit more specifically than) its equivalent under the New Act, as "the main object of promoting religion, arts, sciences, education, charity, recreation, or any other cultural or social activity or communal or group interests" (emphasis added). ${ }^{17}$ If the expression "group interests" were to be construed without any limitation then, as cogently pointed out in Cuninghame, ${ }^{18}$ the preceding references in the section (to religion, arts, sciences and so forth) would hardly have had any meaning. The shareholders and members of most companies are in fact a group with a common interest, which in the case of commercial companies is the pursuit of profit or gain. Accordingly the phrase "communal or group interests" cannot be given such a wide meaning as would render the section nugatory; it must mean a communal or group interest of a charitable, benevolent, cultural or social nature, and must exclude communal or group interests of a commercial nature. ${ }^{19}$

This sound reasoning and logical construction, applying the eiusdem generis interpretation, remains equally applicable to the new statutory provision on non-profit companies, because of the similarity in the wording of the New Act. $^{20}$ This is bolstered by the memorandum on the objects of the Companies Bill, 2008, which specifically states that the new non-profit company is intended to be the successor to the previous section 21 company

15 Id, para 34.

16 Id, paras 19 and 25.

171973 Act, sec 21(1)(b).

18 Above at note 12, para 19.

19 Ibid.

20 As originally submitted by MF Cassim "Types of companies" in FHI Cassim (managing ed), MF Cassim, R Cassim, R Jooste, J Shev and J Yeats Contemporary Company Law (2011, Juta and Co Ltd) 62 at 83-84. 
under the 1973 Act, and is intended to retain the established legal principles relating to the objects or purposes of such companies. ${ }^{21}$

\section{The purpose of the provision and the mischief at which it is aimed}

The interpretation of the phrase "communal or group interests" is further informed by the purpose of the provision and the mischief that it aims to prevent. The Supreme Court of Appeal in Cuninghame examined the mischief at which the section is aimed. ${ }^{22}$

Importantly, the objective ${ }^{23}$ is essentially to preclude companies that "are engaged in ordinary business enterprise both commercial and industrial" and which "are being carried on in competition with ordinary taxpayers" from being incorporated as non-profit or section 21 companies. Although these companies are not permitted to pay dividends, it was observed that in some cases "very substantial salaries" were instead being paid.

The reason for the inclusion of the phrase "communal or group interests" in the section ${ }^{24}$ is to avoid restricting the use of non-profit companies solely to associations that pursue the relevant activities in the wider and broader interests of the general public, while unduly (and unintentionally) excluding certain relevant organizations, for instance local sports organizations, from the ambit of the section. The underpinning purpose of the expression "communal or group interests" is that the charitable, cultural, social, etc activity of a non-profit company need not necessarily be in the interests of the general public at large, but may alternatively be in the narrower interests of a particular community or group.

This fundamental intention of the legislature comes across even more plainly and strongly in the New Act as contrasted with the 1973 Act. The New Act (in terms of item 1(1)(a) of schedule 1) ${ }^{25}$ draws a clear cut distinction between the two categories of objects (ie those in the wider interests of the

21 "Memorandum on the objects of the Companies Bill, 2008" in the Companies Bill [B 61D-2008] at para 4. Furthermore, like a sec 21 company (see sec 21(2)(a) of the 1973 Act), the new non-profit company retains the restriction on the distribution of its income and property to its members, subject to reasonable exceptions. The New Act is also intended to retain the basic principle that the distribution of any residual assets of the company on dissolution is restricted. In this regard, on the winding-up or dissolution of both a non-profit company and a sec 21 company, no member or director is entitled to any part of the net value of the company, and this must instead be distributed to one or more non-profit companies or sec 21 companies, as the case may be, or other bodies that have objects similar to its main object (New Act, sched 1, item 1(4); 1973 Act, sec 21(2)(b)).

22 Above at note 12, para 24

23 According to the main report of the Commission of Enquiry into the Companies Act: RP 45/1970 of 15 April 1970, para 25.02(c).

24 Id, para 25.02(d); Cuninghame, para 24.

25 This item provides, in respect of the objects of a non-profit company: "each such object 
general public and those in the narrower interests of a community or group), by splitting or subdividing them. In this regard, a "public benefit object", which may be regarded as an object in the wider interest of the general public or even a section of the public, such as a charitable or benevolent object, is dealt with in one subparagraph. Another, distinct subparagraph deals separately with an "an object relating to one or more cultural or social activities, or communal or group interests", that is, an object that is not necessarily in the interests of the general public but which is a cultural or social activity in the narrower interests of a particular community or group, such as a local sports organization, social club or residential association.

Notably, the draftsmen of the New Act elected not to treat "communal or group interests" as a stand-alone category of objects, but rather opted to include them as part of the second category of cultural or social activities. This powerfully suggests that the legislature's intention is that the expression "communal or group interests" is not in itself a stand-alone object, but must be read eiusdem generis so as to refer to activities of a cultural or social nature as distinct from commercial ones.

The first category, that of a public benefit object, may broadly be regarded as a public or charitable purpose which is for the betterment of society as a whole. The South African Income Tax Act 58 of 1962, for instance, refers in its definition of "public benefit activity" to activities "of a benevolent nature, having regard to the needs, interests and well-being of the general public". It includes in its list of public benefit activities ${ }^{26}$ matters related to: welfare and humanitarian activities; health care; land and housing; education and development; religion, belief or philosophy; cultural activities; conservation, environment and animal welfare; research and consumer rights; and nonprofessional sport as a pastime. Significantly, a non-profit company that complies with the New Act does not necessarily or automatically qualify for any tax exemption or tax advantages, ${ }^{27}$ unless it satisfies the specific requirements of the Income Tax Act.

Of course, non-profit activities need not necessarily be charitable or benevolent, and may instead be for the mutual benefit of the members of the company, as for instance in the case of social clubs, homeowners' associations or local sports organizations, provided that the purpose or object is not commercial in nature. The second broad category of objects, "an object relating to one or more cultural or social activities, or communal or group interests", may function as a catch-all class for those non-profit companies that do not operate in the general public interest, but rather tend to have objects relating to

contd

must be either - (i) a public benefit object; or (ii) an object relating to one or more cultural or social activities, or communal or group interests".

26 South African Income Tax Act 58 of 1962, sec 30(1) and 9th sched, which sets out a list of public benefit activities for the purposes of that act.

New Act, sched 1, item 1(6). 
cultural or social activities for the benefit of a community or group of individuals, or even entities. It is likely that the pursuit of "group" interests would require at least a group with common interests, in contradistinction to a group whose members have conflicting interests. This accords with a dictum of the Supreme Court of Appeal in Cuninghame 28 in relation to the 1973 Act. As for the types of activities or interests that would qualify as "cultural or social" communal or group interests, it is relevant that the main object of the equivalent section 21 company, as defined in the comparable provision of the 1973 Act, bears obvious resemblance to that under the New Act, save that the 1973 Act defines the main objects of the company far more specifically by referring to "the main object of promoting religion, arts, sciences, education, charity, recreation, or any other cultural or social activity or communal or group interests" (emphasis added). ${ }^{29}$ However, "cultural or social" activities or interests may conceivably have a range far wider than the listed activities of religion, arts, sciences, education, charity and recreation, so as to encompass a variety of other diverse activities. For this reason, the underlying policy decision to refer simply in the New Act to "cultural or social" activities in a broad general sense, while steering clear of a detailed list of particular types of objects is apt. It sidesteps the risk of any undue restriction or limitation of the permissible objects of non-profit companies to those specifically listed. It is regrettable, however, that the statutory provision does not go so far as to exclude explicitly a commercial object. This would have removed any lingering doubt on this matter.

The second category of non-profit companies with objects "relating to one or more cultural or social activities, or communal or group interests" would net a wide assortment of activities. It may encompass, for instance, social or recreational clubs which may inter alia be incorporated as non-profit companies, provided that their stated objects comprise the provision of social and recreational amenities or facilities for their members, and given that they comply with the other essential element for non-profit companies: the proscription of distributions of the company's income and property to its members or controllers. It is interesting that the South African Income Tax Act was recently amended to define a "recreational club" with specific reference to the new non-profit company under the New Act. ${ }^{30}$ A further example is a homeowners' association, which could also constitute a type of "communal or group interest" of a "cultural or social" nature. However, see further the discussion of rental pool arrangements below.

A business association or professional association for the promotion of the common interest of persons, being members of the company, who carry on any particular kind of business, profession or occupation, may seemingly also be incorporated as a non-profit company in this category, so long as its

\footnotetext{
28 Above at note 12, para 25.

291973 Act, sec 21(1)(b).

30 Income Tax Act 58 of 1962 (as amended by sec 54(1)(a) of Act 7 of 2010), sec 30A(1).
} 
object or purpose is not commercial. This too would constitute a type of "communal or group interest" of a "cultural or social" nature. However it should not, for instance, be formed for the purpose of increasing the business and profits of its members, even in an incidental or indirect manner. In this regard, a fine distinction must be drawn between a commercial object on the one hand and the promotion of the common interests of persons involved in a particular type of business on the other hand (see further the discussion below of the term "gain"). Such non-profit business or professional associations would often be substantially or wholly funded by their annual or longterm members. Pertinently, the New Act permits a membership cost for a nonprofit company, whether it be an initial or periodic cost of membership. ${ }^{31}$

\section{The criterion of "gain" as a distinction between profit and non-profit companies}

A further indicator of the legislative intent to preclude non-profit companies from engaging in purely commercial enterprise comes to light from the definition of a "non-profit company" compared with that of a "profit company". The New Act specifically defines a profit company as "a company incorporated for the purpose of financial gain for its shareholders" (emphasis added), whereas a non-profit company is defined as a company that is incorporated for a public benefit or other relevant object, and is subject to a prohibition on distributions to members. ${ }^{32}$ Read together, the implication of the two definitions is that, in contrast with a profit company which has financial "gain" at its heart, a non-profit company must not be incorporated for the primary purpose of financial gain for its members.

This clearly embraces the essential rule that a non-profit company must not make distributions to its members of its profits, income or assets. However the further question arises as to the meaning and latitude of the term "gain" as a distinguishing criterion of profit and non-profit companies.

It was held in Mitchell's Plain Town Centre Merchants Association $v$ McLeod (Mitchell's Plain) that: “'[g]ain' ... means a commercial or material benefit or advantage... in contradistinction to the kind of benefit or result which a charitable, benevolent, humanitarian ... or sporting organisation, for instance, seeks to achieve". ${ }^{33}$ The English case of Re Arthur Average Association for British, Foreign and Colonial Ships, Ex parte Hargrove $\mathcal{E}$ Co, ${ }^{34}$ which was referred to with approval in South African Flour Millers' Mutual Association v

31 New Act, sched 1, item 4(2)(e)(iii). The Income Tax Act 58 of 1962 (sec 30B(1)) now also envisages that a non-profit company may be established "to promote the common interests of persons (being members of the company) carrying on any particular kind of business, profession or occupation".

32 New Act, sec 1.

331996 (4) SA 159 (A) at 169J - 170A.

34 (1875) 10 Ch App 542 at 545. South African company law has traditionally been based on English company law, as discussed further below. 
Rutowitz Flour Mills Ltd (South African Flour Millers), 35 likewise stated: “[n]ow, if you come to the meaning of the word 'gain', it means acquisition. It has no other meaning that I am aware of ... It distinguishes ... between commercial undertakings on the one hand ... and what we may call literary or charitable associations on the other hand, in which persons associate, not with a view to obtaining a personal advantage, but for the purpose of promoting literature, science, art, charity or something of that kind." 36

It was moreover laid down in Mitchell's Plain (although not referred to in Cuninghame) that the element of "gain" need not necessarily be a pecuniary profit. In other words, gain is wider than profit. Likewise, in South African Flour Millers, the court held that "gain" may be "in the form of profit or anything else, provided it is something commercial as distinct from literary, scientific or charitable". ${ }^{37}$ It must be stressed that, according to Mitchell's Plain, the "gain" by the individual members of the company (or association) need not necessarily be direct (for instance, a distribution, loan or dividend) but may also be indirect, in the sense of gain that does not derive strictly from the association itself. ${ }^{38}$

Mitchell's Plain serves as a useful illustration of this principle. On the facts, the constitution of the appellant specified two ultimate objects: to promote the popularity of a trading centre, first as an integral part of the community and, secondly, as a means of increasing the volume of trade and advancing the prosperity of the trading centre and its members. The constitution further provided that the income and property of the appellant (an association) were to be applied solely towards the promotion of its objects, and that no portion would be paid to the members except as remuneration for services rendered. The court reasoned that the benefit to the members, which derived from the appellant's second object, was a by-product of the appellant's advertising campaign and other arrangements and was, as such, an indirect gain as opposed to a direct gain (such as a distribution, loan or dividend derived directly from the association). The court nonetheless found that this had still amounted to the carrying on of business with the object of the acquisition of "gain", because it had in mind a commercial or material benefit or advantage (which need not necessarily be a pecuniary profit) for the members.

351938 CPD 199 at 202.

36 These two dicta were referred to in Cuninghame at para 22, ie in the context of an "association not for gain" (as per the heading of sec 21 of the $1973 \mathrm{Act}$ ) which is now an obsolete term under the New Act. It is submitted that the interpretation in Cuninghame of the term "gain" nonetheless remains relevant to the New Act, albeit in quite a different context, in view of the use of the term "gain" as the crux of the definition of a profit company. It is also relevant in this regard that the Supreme Court of Appeal in Cuninghame relied on Mitchell's Plain even though it concerned a different provision of the 1973 Act (viz secs 30(1) and 31, as opposed to sec 21), on the basis that the meaning of "gain" should be the same.

37 Above at note 35 at 202-04.

38 Above at note 33 at 169-70. 
There is no reason in principle why the same meaning of the word "gain" should not also be applied to the term "financial gain" insofar as it forms part of the definition of profit companies under the New Act. ${ }^{39}$ It may accordingly be surmised that the heart of the definition of a profit company is its incorporation for the purpose of financial "gain" for its shareholders, whereas in stark contrast a non-profit company is proscribed from having as its object the pursuit of the financial gain of its members, in the sense of a commercial or material benefit or advantage, whether this be in the form of pecuniary profit or otherwise, and whether it derives directly from the company itself or indirectly. Non-profit companies are consequently barred from engaging in commercial undertakings in a wide and expansive sense.

\section{THE CONTOURS OF PROFIT-MAKING ACTIVITIES BY NON-PROFIT COMPANIES}

It must be underscored that, even though a non-profit company may not be incorporated for a purely profit-making or commercial purpose, such a company is not necessarily precluded from making any profit at all. In this regard, a non-profit company has the scope, under the New Act, to carry on any business ${ }^{40}$ trade or undertaking, whether it does so directly or indirectly, or alone or with any other person. A non-profit company may also acquire and hold securities issued by a profit company. ${ }^{41}$

Crucially however, any business, trade or undertaking carried on by a nonprofit company is subject to the qualification that it must be "consistent with or ancillary to its stated objects". ${ }^{42}$ This clearly means it cannot be some business, trade or undertaking that is unrelated to or inconsistent with the stated objects of the non-profit company, nor may the business, trade or undertaking be the main purpose or the stated object of the company.

Furthermore, any profits, income or assets that are derived from such business or trading activity must be strictly applied to advance the stated (noncommercial) objects of the non-profit company, as set out in its constitution. ${ }^{43}$ The profits may not, of course, be distributed to the incorporators, members, directors, officers or related persons of the non-profit company. In a similar vein, the predecessor to the non-profit company (ie the section 21 company) was not entirely prohibited from making any profit at all, so long as its

39 As noted in note 36 above, it is also relevant that the Supreme Court of Appeal in Cuninghame relied on Mitchell's Plain even though that case concerned a different statutory provision, on the basis that the meaning of "gain" should nevertheless be the same. The definition of "business" as laid down in Smith v Anderson [1880] 15 Ch 247 (CA) 258 and adopted in South African law, is "everything which occupies the time and attention and labour of man for the purpose of profit".

41 New Act, sched 1, item 1(2)(b).

42 Id, item 1(2)(b)(ii).

43 Id, item 1(2)(a). 
profits or other income were applied to promote its stated (non-commercial) objects. $^{44}$

As a matter of policy, by permitting non-profit companies to make profits from an ancillary business, trade or undertaking and to use those profits to promote their non-commercial purpose or object, the New Act ensures that non-profit companies are not exclusively reliant on external sources of funding, such as donations or some form of public funding (or in some cases membership payments), bearing in mind that such sources of funding are often irregular, unpredictable or even insufficient. This sort of flexibility enables non-profit companies to carry out their stated non-commercial objects more effectively, and to maintain their operations, facilities and staff.

It merits emphasis that, where a company engages in a trivial or insignificant profit-making activity, this must not be used to distort the true picture: for example, where charitable or humanitarian associations charge a small fee for tea or snacks, or where an art club efficiently ensures that its subscriptions exceed its expenses, thereby leaving it with a monthly profit to ensure its continued existence, or to pay the travel expenses and lecture fees of an art expert for the benefit of the club members, ${ }^{45}$ or where a non-profit museum sells replicas of works in a gift shop.

In the case of Huey Extreme Club v McDonald t/a Sport Helicopters, ${ }^{46}$ the applicant club was a voluntary association which offered membership, including day-membership, entitling new members to flights around the Cape Peninsula on the legendary Huey helicopter. Its main object, according to its constitution, was to foster and develop enthusiasm in the aviation industry through the development of opportunities for helicopter enthusiasts. The club also made the Huey helicopter available to qualified pilots, who were often club members, on a "hire and fly" basis. It was contended by the respondent that the applicant club was running a commercial operation and was, as such, an unlawful association for gain in view of its lack of registration under section 30 of the 1973 Act. The court, however, rejected this contention and ruled that the club was primarily a social organization that was centred on a sporting activity. The critical question, accordingly, is not whether an association or a non-profit company makes a profit, but rather whether profitmaking or commercial activity is its main purpose or object.

The gist of the matter is therefore that profit-making activity may not be the main or primary purpose or object of a non-profit company; it may at best be only a secondary activity that is consistent with or ancillary to the company's non-commercial objects and that is used as a means of promoting and advancing the company's non-commercial objects.

441973 Act, sec 21(1)(c); see also Cuninghame, above at note 12, para 19.

45 Based on a similar example to that in used by the court in Huey Extreme Club v McDonald t/a Sport Helicopters [2004] 3 All SA 702 (C), para 19.

46 Ibid. See also FHI Cassim "Companies (including close corporations)" in Annual Survey of South African Law 2005 (2007, Juta and Co Ltd) 466 at 473-74. 


\section{To sum up}

To sum up the legal position on the undertaking of commercial activities by non-profit companies under the New Act, it is respectfully submitted that there are twin qualifying criteria for a non-profit company, which arise from its definition. First, it is essential that the income and property of the company must not be distributable to its members, controllers or other persons (except as permitted by item 1(3) of schedule 1 of the act). Secondly, the company must be incorporated for a suitable object, as stated in its constitution, which must not be a purely commercial object or an object involving the pursuit of profit or gain.

Subject to these two essential criteria, a non-profit company may carry on a business, trade or undertaking that is ancillary to or consistent with its noncommercial stated objects, provided that any profits made are applied only to advance the company's non-commercial objects.

Both criteria must be satisfied for a company to qualify as a non-profit company. It consequently cannot be correctly contended in South African law that non-profit companies may validly engage in commercial objects or purely commercial enterprises, so long as no distributions are made to members and the profits are used to advance the company's commercial objects; such a contention would not only be misguided but would be unsupported by authority.

It is instructive and enlightening to consider briefly rental pool agreements (which arose on the facts of Cuninghame). The issue of rental pool agreements illustrates the scope and meaning of unlawful "commercial" activities conducted by non-profit companies.

\section{RENTAL POOL AGREEMENTS: COMMERCIAL OR NON-PROFIT OBJECT?}

The factual background of Cuninghame is important as a starting point to the discussion of rental pool agreements.

\section{The facts and decision in Cuninghame}

A conference hotel was registered as a sectional title scheme, in which the sectional title units comprised the hotel rooms. The commercial areas, including the parking garage, conference centre and restaurants, did not form part of the common property for the benefit of the owners of the room units, but had to be rented from the owner of the commercial areas.

The developer (Casisles Property Investments CC) had concluded agreements of sale with the individual purchasers of hotel room units. The room units were bought, not for occupation by their purchasers, but for investment purposes and were intended to be rented out to guests as part of the hotel operation. The standard deed of sale of a room unit incorporated a rental pool agreement, which envisaged that all the owners of units to be used as hotel rooms would participate in a rental pool, and would let the hotel rooms 
linked to their sectional title units to a management company, Harbour's Edge Pty (Ltd) (HEH), which would administer and manage the rental pool. HEH also undertook to contract with a hotel operator, Villa Via Cape Town (Pty) Ltd, to conduct the actual running of the hotel. As a return on their investment, the total revenue received for hotel accommodation, minus operating expenditure, was to be pooled and apportioned among the unit owners by HEH in accordance with the terms of the rental pool agreement.

When HEH and the developer were subsequently placed under liquidation, the management of the rental pool was eventually taken over by the respondent, First Ready Development 249, a section 21 company (or non-profit company).

Some time later, when the respondent's relationship with Villa Via Cape Town (Pty) Ltd ceased, the respondent company assumed the dual functions of managing the rental pool and of conducting the business of the hotel. The question arose whether the respondent's operation was unlawful and in contravention of section 21(1)(b) of the 1973 Act, which required a section 21 company to have "the main object of promoting religion, arts, sciences, education, charity, recreation, or any other cultural or social activity or communal or group interests".

The Supreme Court of Appeal found ${ }^{47}$ that, when the respondent's functions had been expanded to include not only the management of the rental pool but also the operation of the hotel, its main object had changed from managing a rental pool on a non-profit basis to the management of the hotel business as a whole. Applying the legal principles discussed above, and in view of the court's finding that the reference to "communal or group interests" in section 21(1)(b) excluded purely commercial enterprises, the court proclaimed that the respondent's conduct of a commercial hotel business for the benefit of its members amounted to a purely commercial enterprise, which consequently fell outside the ambit of what the object of a section 21 company may lawfully be. ${ }^{48}$ The company therefore had to be liquidated.

The issue in Cuninghame was further complicated by the fact that there were conflicting interests between the members of the respondent, First Ready Development 249. The two conflicting groups were, on the one hand, the rental pool owners who were entitled to the net accommodation revenue minus operating expenditure and, on the other, the owners of the commercial areas who were entitled to rent for the commercial areas, which was treated as operating expenditure and was therefore deducted from the net accommodation revenue available for distribution among the rental pool owners. There was thus a conflict of interest between the two groups. This prompted the court to state that the pursuit of "group interests" within the meaning of the act

47 Cuninghame, above at note 12 , para 17.

48 Id, para 25. 
would at least require a group with common interests, as opposed to a group having members with conflicting interests. ${ }^{49}$

\section{Critical analysis of Cuninghame}

It is respectfully submitted that this interpretation of section 21 is clearly correct, insofar as the court laid down the legal principle that purely commercial enterprises are prohibited from being incorporated as section 21 companies (as discussed in detail above).

With respect, one may however question the court's application of this legal principle to the facts of Cuninghame and specifically to the rental pool agreement. One wonders whether the respondent company had in fact been engaged in commercial activity from the time that it had served merely as the manager of the rental pool, and not only from the later time when its functions had been expanded to include the operation of the hotel business. A number of facts are of key importance in this regard. First, as stated by the court, ${ }^{50}$ the room units in Cuninghame were bought in the main, not for the purpose of personal use and occupation, but specifically for investment purposes. Related to this, the purchasers intended their room units to be rented out to hotel guests as part of the hotel operation, and envisaged that the return on their investments would consist in their respective portions of the pooled hotel accommodation revenue (after deduction of the hotel operating expenditure). Secondly, the rental pool agreement formed part of the standard deed of sale, and envisaged that all the owners of the units to be used as hotel rooms would participate in the rental pool. It therefore seems that, on a proper analysis and application of the legal principles, the respondent's conduct of the rental pool operation had, in itself, constituted commercial activity, in violation of what the lawful objects of a section 21 company or non-profit company may be. This issue of rental pool agreements as commercial activity is elaborated on below.

\section{Rental pool agreements: An illustration of a "commercial" object}

A careful distinction must be drawn between two distinct types of activities. On the one hand, where the purchasers or tenants of a block of flats or apartments occupy their own units for residential purposes and use a company to attend to the care and maintenance of the common areas, which company is funded by way of service charges only to the extent needed to discharge its obligations, this may properly be regarded as a non-profit purpose ${ }^{51}$ (or, to be more specific, a "communal or group interest" of a social nature) as

49 Ibid.

50 Id, para 4.

51 See for example PL Davies Gower and Davies' Principles of Modern Company Law (8th ed, 2008, Sweet \& Maxwell) at 8 for the position under English law. 
opposed to a commercial purpose. On the other hand, where the purchasers of apartments or hotel room units enter into a rental pool arrangement, whereby the developer's agent or a third party is responsible for renting and managing the units, and in terms of which each participant in the rental pool arrangement receives a pro rata share of the pooled income (and expenses) earned on the rental of the units, this could well amount to a profitmaking or commercial enterprise.

It has been held in US law, for instance, that if a purchaser enters into a rental pool agreement in respect of a condominium unit in a resort complex, ${ }^{52}$ this would qualify as an "investment contract", which has the goal of profit realization. ${ }^{53}$ In the USA, it is accepted that the true purpose of a rental pool arrangement is profit realization. The rental pool scenario is distinguished in the USA from the contrasting scenario of the traditional owneroccupied unit, where investors in a co-operative housing project purchase their units solely to acquire a place to live, and not out of a reasonable expectation of profits. The latter arrangement, unlike the rental pool arrangement, has been found to lack a profit-seeking purpose. ${ }^{54}$ Similarly, where the developers of a condominium project continue their affiliation with the project by reason of maintenance arrangements, or where a condominium owner voluntarily enters into a non-pooled rental arrangement with an agent of his choice, these arrangements do not involve profit-seeking purposes..$^{55}$

It is respectfully submitted that this is undoubtedly a logical distinction; a similar distinction ought to be drawn in South African law between, on the one hand, the purchase of room units for personal use and occupation coupled with maintenance arrangements to be performed by a non-profit company and, on the other, the purchase of room units that are bought as an investment with an expectation of profits from a rental pool arrangement administered by a non-profit company. While the former would constitute a proper non-profit purpose which serves the social "communal or group interests" of the purchasers, the latter would arguably amount to a commercial purpose and thus an unlawful object for a non-profit company.

On this basis it is submitted, with respect, that the Supreme Court of Appeal in Cuninghame ought to have analysed and considered more closely whether the respondent company had in fact been engaged in commercial activity

52 See for example Hocking $v$ Dubois 839 F 2d 560 (9th cir 1988).

53 An "investment contract" is a contract, transaction or scheme for the placing of capital or laying out of money in a way intended to secure income or profits from its employment. The classic definition of an "investment contract", as laid down in SEC $v$ WJ Howey 328 US 293 (1946), entails inter alia that the purpose or goal must be profit realization. Although investment contracts concern US federal securities law, it is submitted that the Howey test is relevant to the meaning and interpretation of a profit-making purpose or commercial object.

54 United Housing Foundation, Inc v Forman 421 US 837 (1974).

55 See the US Securities and Exchange Commission release no 33-5347 (4 January 1973): guidelines on the offering of condominium units. 
even at the time that it had only managed the rental pool. It must be borne in mind that the hotel room units in Cuninghame were bought mainly for investment purposes. Moreover, the rental pool agreement was part of the standard deed of sale which was entered into by all the owners of the units to be used as hotel rooms. The respondent section 21 company took responsibility for the administration of the rental pool as well as for contracting with a hotel operator to conduct the actual running of the hotel. Significantly, its main business included the letting and marketing of the hotel units. Such an arrangement, on the facts of the case as related by the court, could well amount to a commercial object in the pursuit of profit or "gain" for the members and, as such, is a violation of the lawful objects of a section 21 or nonprofit company. (See also the discussion above on the meaning of the term "gain" in this context.) The details of Cuninghame and the issue of rental pool arrangements thus provide a useful example of the scope and breadth of unlawful commercial or profit-making objects of non-profit companies.

\section{A COMPARATIVE LAW PERSPECTIVE: ESSENTIAL CRITERIA OF NON-PROFIT COMPANIES}

It is useful to consider, albeit cursorily, the legal position of non-profit companies in other comparable jurisdictions, with a particular focus on the boundaries and contours of profit-making activities and the undertaking of purely commercial enterprises.

Although South African company law has traditionally and historically been based on English company law, a number of new trends and concepts have been adopted from US and Canadian corporate law for the purposes of the New Act. Indeed the new term "non-profit" company has itself evidently been imported from the USA and Canada and is now set to replace the previous terminology "association not for gain".

As submitted above, there are twin criteria for a South African company to qualify as a non-profit company, as emerges from the definition in the New Act and as supported by judicial authority. The two criteria are: the prohibition on distributions of income and property to the members of the company; and the incorporation of the company for a suitable, non-commercial object. While the first criterion is widely accepted in comparable jurisdictions as a defining characteristic of non-profit companies, the second criterion has given rise to some degree of confusion, not only in South Africa (as arose on the facts of Cuninghame) but also more widely in other jurisdictions. ${ }^{56}$

In the USA and Canada, unlike South Africa, separate statutes govern nonprofit corporations and business corporations, flowing from a clear

56 For example see generally: Oleck "Mixtures of profit and non-profit", above at note 7 at 225; Hansmann "Reforming non-profit corporation law", above at note 7 at 497; LA Moody "The who, what, and how of the Revised Model Non-profit Corporation Act" (1988) 16 Northern Kentucky Law Review 251. 
recognition of the fundamental differences between the two entities. In the USA, the Model Business Corporation Act ${ }^{57}$ regulates business corporations, while non-profit corporations are regulated by the Model Non-profit Corporation Act. ${ }^{58}$ The US Model Acts are designed to serve as a basic guideline or model for state legislation, which individual US states may tailor or adapt to suit their particular needs. In Canada the separate statute governing federally incorporated non-profit corporations is the Canada Not-for-profit Corporations Act, ${ }^{59}$ which recently replaced the previous governing legislation, namely part II of the Canada Corporations Act. ${ }^{60}$ As a matter of policy, the statutes regulating non-profit corporations in the USA ${ }^{61}$ and Canada closely parallel those regulating business corporations, and tend to follow much of the same law.

A non-profit corporation was defined in the earlier (1964) version of the US Model Non-Profit Corporation Act as "a corporation no part of the income or profit of which is distributable to its members, directors or officers". ${ }^{62}$ This significantly parallels the first essential criterion for non-profit companies under the New Act: a restriction on distributions to members and controllers. Indeed this criterion is regarded as the defining characteristic of US non-profit corporations, which is universally applied throughout most of the US states.

As for the purposes of non-profit corporations, the 1964 (and 1952) version of the US Model Non-Profit Corporation Act stated that a non-profit corporation could incorporate for any lawful purpose, and provided a nonexhaustive list of purposes, including: "charitable; benevolent; eleemosynary; educational; civic; patriotic; political; religious; social; fraternal; literary; cultural; athletic; scientific; agricultural; horticultural; animal husbandry; and professional, commercial, industrial or trade association". ${ }^{63}$ Although this list did not explicitly preclude the incorporation of non-profit corporations for commercial or profit-making purposes, it was stated in the preface to the act by the drafting committee that "[t]he most difficult decision of policy in drafting the Model [Act] is the determination of the purposes for which corporations may be organized under it." As observed by Professor Moody, while business corporations are generally organized for profit-making for shareholders, the vast diversity of purposes of non-profit corporations makes it difficult to find a "similar commonality which will apply in each instance". ${ }^{64}$ The preface to the act further stated that "[a] majority of the Committee are of the

57 (1984), as amended.

58 Third edition (2008).

59 SC 2009 c 23.

60 RSC 1970.

61 LA Moody "Revising the Model Non-profit Corporation Act: Plus ça change, plus c'est la même chose” (2006-07) 41 Georgia Law Review 1335 at 1346.

62 Sec 2(c). A similar definition appeared in the Model Non-profit Corporation Act (1952) at $\sec 2(\mathrm{c})$.

63 Sec 3.01

64 Moody "The who, what, and how", above at note 56 at 266. 
opinion that the purposes should be limited to those which are not for pecuniary profit". Some degree of recognition was thus given to the criterion that non-profit corporations must have a suitable purpose or object, of a noncommercial nature. This broadly mirrored the second of the twin essential criteria for South African non-profit companies.

Whereas the earlier versions of the US Model Act applied generally to all non-profit corporations, the Revised Model Non-profit Corporation Act (1987) (Revised Act) classified non-profit corporations into three categories, based on Californian non-profit corporation law, namely: public benefit corporations, which functioned in the interests of society as a whole and were generally exempt from paying income tax; mutual benefit corporations, which operated not in the wider public interest but for the benefit of a group of individuals or entities (such as a social club or homeowners' association); and religious corporations. More importantly, the drafters of the Revised Act elected to omit any definition of a non-profit corporation as well as any list of their proper purposes, due largely to the difficulty of determining the proper purposes. The Revised Act simply stated in very broad terms: "[e]very corporation incorporated under [the Act] has the purpose of engaging in any lawful activity unless a more limited purpose is set forth in the articles of incorporation." 65 The official comment to that section nevertheless cautioned that "[t]he failure to set forth an explicit limitation on a nonprofit corporation's activities does not mean that an enterprising entrepreneur can improperly and with impunity operate in the non-profit form". ${ }^{66}$ The recently completed Model Non-profit Corporation Act, Third Edition (2008) adopts a similar approach by avoiding any definition or list of purposes of a non-profit corporation. Interestingly, it once again abandons the classification of non-profit corporations and applies generally to all such corporations. ${ }^{67}$ It is significant for the purposes of this article and the question of non-profit companies engaging in purely commercial activities that, in the USA, considerable concerns and criticisms have been levelled at the very wide provisions of the Revised Act on the purposes of non-profit corporations. Dissatisfaction stems especially from the concern that it creates scope for or even "invite[s] entrepreneurial activities to masquerade under the non-profit umbrella". ${ }^{6}$

While most US states have adopted in their state legislation provisions from the Revised Act, several US states shared the concern that entities engaged in entrepreneurial activities ought not to be given any scope to incorporate as non-profit corporations. These US states therefore opted under their state

65 Sec 3.01(a).

66 This takes account of the constraint on distributions to members and controllers.

67 Save for the retention of a very few provisions that apply specifically to charitable or religious corporations.

68 Moody "The who, what, and how", above at note 56 at 262. See for example Oleck "Mixtures of profit and non-profit", above at note 7 at 245. 
legislation for a divergent approach to the definition and the proper purposes of non-profit corporations. Not only were explicit definitions of a non-profit corporation included, but also in several cases express limitations to their proper purposes. In Ohio, for instance, a non-profit corporation is expressly defined as a corporation "that is formed otherwise than for the pecuniary gain or profit of, and whose net earnings or any part of them is [sic] not distributable to, its members, directors, officers, or other private persons" (emphasis added) provided, however, that the payment of reasonable compensation for services rendered shall not be deemed pecuniary gain or profit. ${ }^{69}$ The purpose for which the corporation is formed must also be set out in the articles of incorporation..$^{70}$ Ohio's statutory definition has been commended as "a masterpiece of clarity and detailed explanation" that "overall, represents one of the most reasonable and complete schemes in the nation". ${ }^{71}$ The Illinois legislation on the face of it has broad congruencies with the twin essential elements identified above for South African non-profit companies: constraints on distributions to members and controllers, and a proper, non-commercial purpose or object. The Illinois provision ${ }^{72}$ goes further than the equivalent South African provisions in that it specifically states that not-for-profit corporations may be organized for any one or more of 33 listed or similar purposes, which prominently exclude a purely commercial purpose.

In New York state a non-profit corporation is defined as being formed: "exclusively for a purpose or purposes, not for pecuniary profit or financial gain, ... and ... no part of the assets, income or profit of which is distributable to, or enures to the benefit of, its members, directors or officers except to the extent permitted under this statute"73 (emphasis added). On the face of it, this definition appears to exclude New York non-profit corporations from both profitmaking or financially gainful purposes as well as distributions to members. It must, however, be pointed out that the meaning of the phrase "not for pecuniary profit or financial gain" is ambiguous and has been subjected to much debate. On the one hand, the phrase may be interpreted to relate merely to the generally accepted principle that non-profit corporations are subject to constraints on distributions to members. On the other hand, it was decided

69 Ohio Revised Code, Non-profit Corporation Law, sec 1702.01(C).

70 Id, sec 1702.04(A).

71 Oleck "Mixtures of profit and non-profit", above at note 7 at 235

722005 Illinois Code / General Not For Profit Corporation Act of 1986 art 3, sec 103.05(a). See also the definition of a not-for-profit corporation in sec 103.05.

73 New York State Not-For-Profit Corporation Law (1970) art 1, sec 102(a)(5); 2006 New York Code sec 102(a)(5). However, the New York legislation then confusingly continues to classify (in sec 201) not-for-profit corporations into types A, B, C and D, of which types A and $\mathrm{B}$ may be formed for certain non-business purposes, type $\mathrm{C}$ for any lawful business purpose to achieve a lawful public or quasi-public objective and type $\mathrm{D}$ (which is intended simply as a connector to other special purpose statutes governing particular types of non-profits) which may ambiguously be formed for a business or non-business, pecuniary or non-pecuniary purpose specified in other corporate laws of the state. 
in People ex rel Bonney $v$ Rose $e^{74}$ that this wording has a greater impact and that it effectively excludes, from the purview of non-profit corporations, any corporations that are formed solely for business purposes. This excludes, for instance, a Chicago street railway company (ie a corporation with a commercial purpose) financed by user fees and excluding any distribution of profits to members. This case consequently lends support to both of the pivotal twin criteria for non-profit companies. There are thus divergent approaches among individual US states, coupled with a fair degree of confusion on and attendant criticism of the definition and purposes of non-profit corporations.

To turn to the Canadian approach, there were clear congruencies between the Canadian and South African principles on non-profit corporations. The contours and limits of permissible profit-making activity by Canadian nonprofit corporations under the Canada Corporations Act, ${ }^{75}$ are particularly instructive. Federally incorporated Canadian non-profit corporations were formerly regulated by part II of this act, which provided that a corporation without a share capital (commonly known as a not-for-profit corporation or non-profit corporation) is formed "for the purpose of carrying on, without pecuniary gain to its members, objects, to which the legislative authority of the Parliament of Canada extends, of a national, patriotic, religious, philanthropic, charitable, scientific, artistic, social, professional or sporting character, or the like objects". ${ }^{76}$

Two essential criteria for Canadian non-profit corporations emerged: a prohibition on pecuniary gain to or enrichment of members; and the requirement of a non-profit object as opposed to a commercial object. Business activities as such were not completely prohibited, although they were subject to the important qualifications that the business activities had to be incidental to the corporation's non-profit objects, and that the profits had to be used specifically for the corporation's objects. ${ }^{77}$ It is significant that these principles closely match the new South African approach, not only in respect of the twin essential criteria for non-profit companies but also in respect of the boundaries and limits of their permissible profit-making activities.

Part II of the Canada Corporations Act has recently been repealed and replaced by the Canada Not-for-profit Corporations Act. ${ }^{78}$ This act preserves

74188 IMI 268, 59 NE 432 (1900).

75 RSC 1970.

76 Id, sec 154.

77 In the Ontario Corporations Act, RSO 1990, c 38 for instance, non-profit corporations, which are corporations without share capital and incorporated under part III of that act, are subject to the provision in sec 126(1) that: "A corporation ... shall be carried on without the purpose of gain for its members and any profits and other accretions to the corporation shall be used in promoting its objects" (emphasis added). See also generally RJ Burke-Robertson and A Drake Non-Share Capital Corporations (1996, Thomson-Carswell); Canadian Encyclopedic Digest Associations and Not-for-Profit Corporations (2012, Thomson Reuters Canada Limited) at I.2. 
the fundamental principle that members of non-profit corporations may not share in corporate profits. ${ }^{79}$ It also specifically defines "activities" to be: "any conduct of a corporation to further its mission and any business carried on by a body corporate, but does not include the affairs of a corporation". ${ }^{80}$ This is intended ${ }^{81}$ to highlight the fact that non-profit corporations may only undertake activities that specifically further their missions, as outlined in their mission statements in the articles of incorporation. However, in contrast with the previous legislation, it is notable that this act no longer explicitly restricts non-profit corporations to non-commercial objects. ${ }^{82}$

The United Kingdom does not have a concept of a "non-profit company" as a term of art or as a specific type of company. The UK company limited by guarantee, ${ }^{83}$ which does not have share capital or shareholders, is often used for charitable and quasi-charitable purposes and for carrying on non-profit activities. This type of company is widely used for community and sporting groups, local associations, flat management companies, and educational and charitable purposes. The company limited by guarantee may, however, also be used for trading purposes and, conversely, companies limited by shares may be used for non-profit purposes. ${ }^{84}$ Contrary to a common misperception, ${ }^{85}$ not all UK companies limited by guarantee are subject to a general prohibition on the distribution of their profits to their members.

However some UK companies limited by guarantee are exempt from using the word "limited" in their names. ${ }^{86}$ Significantly, the exemption may be granted if the company's objects are the promotion of commerce, ${ }^{87}$ art, science, education, religion, charity or any profession, and provided that the constitution requires any profits or other income to be applied in promoting the company's objects and prohibits distributions to its members (whether in profit dividends or on winding up). Parallels may be drawn between South African non-profit companies and those UK companies limited by guarantee

79 Id, sec 34.

80 Id, sec 2(1).

81 Commentary to the Bill C-21: Canada Not-for-profit Corporations Act (LS-498E).

82 However it is significant that this statute extends more widely than just to non-profit corporations. Some of its provisions are designed to apply also to other corporations without a share capital, which were previously regulated by part III of the Canada Corporations Act (see the Commentary to the Bill, ibid).

83 Ie a company without a share capital that limits the liability of its members by its constitution to such amount as the members undertake to contribute to the assets of the company in the event if its being wound up (UK Companies Act 2006, sec 3).

84 Davies Gower and Davies', above at note 51 at 8-9. Incidentally, the New Act now departs from the previous 1973 Act by abolishing the concept of the company limited by guarantee in South Africa.

85 B Hannigan Company Law (2nd ed, 2009, Oxford) at 15.

86 Under sec 30 of the Companies Act of 1985 and sec 60 of the Companies Act of 2006.

87 It must be stressed that the "promotion of commerce" under the UK provision must be distinguished from a commercial object and would include, for instance, a chamber of commerce. 
that are exempt from using the word "limited" in their names. In effect, the exemption is available only to charitable companies or those with public interest objectives that cannot be used as vehicles for making a profit for their members. ${ }^{88}$ It may consequently be stated that the twin criteria for South African non-profit companies also form the basis for the UK equivalent of companies limited by guarantee that are exempt from using the word "limited" in their names: both require a prohibition on distributions to members as well as a non-commercial object. Another very important congruence with the South African non-profit company is that, if an exempted UK company limited by guarantee is wound up, its assets must be transferred to another body with similar or charitable objects.

The community interest company ${ }^{89}$ is a relatively new type of company in the UK, which was created in 2004. The purposes of a community interest company, which may be either a company limited by shares or a company limited by guarantee, are restricted to the pursuit of community interests. The statute provides that "[a]n object stated in the memorandum of a company is a community interest object of the company if a reasonable person might consider that the carrying on of activities by the company in furtherance of the object is for the benefit of the community" and that " [c] $]$ ommunity' includes a section of the community". 90 The relevant statutory provisions are geared to meeting community interests, as opposed to making a private profit for the members. Distributions to members are, of course, subject to limitations. Although profitability is required for the continuation or survival of the company, the profits are to be devoted mainly to promoting community objectives. ${ }^{91}$

There is accordingly a substantial degree of congruence and similarity in the basic underlying principles on the quintessence of a non-profit company and its essential defining criteria. However, it is also apparent that there have been divergences and, more importantly, general and widespread confusion about what it means to be a "non-profit" company or corporation and what its lawful purposes ought to be. This sort of confusion in philosophy and policy is not unique to South African law, but is also experienced in other comparable jurisdictions.

\section{CONCLUSION}

Despite the widespread confusion over the basic principles of non-profit companies, it may be stated with confidence, particularly in the context of South African law, that the new Companies Act of 2008 makes it abundantly clear that there are twin pivotal criteria for a non-profit company: not only is a

88 Davies Gower and Davies', above at note 51 at 84.

89 See the Companies (Audit, Investigations and Community Enterprise) Act 2004, sec 26(1).

90 Id, sec 35.

91 Davies Gower and Davies', above at note 51 at 20. 
prohibition on distributions to members and controllers essential, but the company must additionally have an appropriate object or purpose that is not of a commercial nature. The importance of a non-commercial object is clearly recognized and acclaimed in South African law, as are the well-defined boundaries and contours of profit-making activities by non-profit companies. It is desirable that these foundational principles be plainly and openly acknowledged and asserted in South African law. Any further confusion is best avoided and indeed unnecessary in light of the clarity provided by the New Act on the matter. Any residual doubts about the basic tenet that South African non-profit companies are prohibited from pursuing purely commercial activities as their object, may be readily curbed by a proper interpretation of the new statutory provisions, as informed by the cogent exposition of the legal principles by the Supreme Court of Appeal in the case of Cuninghame $v$ First Ready Development 249. 